\title{
Partial replacement of river sand with volcanic pyroclastics as fine aggregates in concrete production
}

\author{
Okwadha G.D.O., Ph.D and Ngengi K.J. \\ Department of Civil \& Construction Engineering, The Technical University of Kenya, P.O. Box 52428-00200 \\ Nairobi, Kenya.
}

\begin{abstract}
The most commonly used fine aggregate in concrete production is river sand. Its extensive mining has led to massive environmental degradation. Volcanic activity in most parts of the world has deposited enormous amounts of pyroclastics especially volcanic tuff and lapilli which can be used to reduce overdependence on river sand. The effects of sand-pyroclastics mixture on workability of fresh concrete, absorption and compressive strength of cured concrete were investigated. Factorial experiments were done with $0 \%, 25 \%, 50 \%, 75 \%$, and 100\% sand replacement by weight of sand. Concrete test cubes were casted in 150 $m m \times 150 \mathrm{~mm} \times 150 \mathrm{~mm}$ cube steel molds with a water-cement ratio of 0.445 , and cured for 28 days. Workability decreased with increase in sand replacement. Water absorption for $150 \times 150 \times 150 \mathrm{~mm}$ concrete test cubes after 28 days curing period increased with increase in the amount of sand replaced. This followed the trend of individual aggregates. Compressive strength increased from $25.6 \mathrm{kNm}^{-2}(0 \%$ sand replacement) to an optimum of $27.8 \mathrm{kNm}^{-2}$ and $27.2 \mathrm{kNm}^{-2}$ at $25 \%$ sand replacement for volcanic tuff and lapilli respectively at 28 days curing period due to the pozzolanic activity of volcanic tuff and lapilli material. The results have shown that replacing sand with up to 50\% volcanic tuff or lapilli can produce lightweight concrete of class 25 . This would reduce the amount of sand used in concrete manufacture with subsequent decrease in environmental degradation associated with mining of river sand.
\end{abstract}

Keywords: Absorption; Lightweight Concrete; Compressive Strength; Environmental degradation; Volcanic Pyroclastics; Pozzolanic.

\section{Introduction}

Rapid economic growth particularly in developing countries has resulted in high demand for infrastructure development. This has increased the construction of concrete structures, and consequently, continued demand for river sand as material for housing and general infrastructure construction. The main source of river sand is river channels especially beds and banks because they provide high quality material at low cost. River sand is particularly desirable because weak materials are eliminated by abrasion and attrition leaving durable, rounded and well-sorted materials that require less processing than many other sources $[1,2]$. But, excessive sand mining in river beds causes degradation of rivers by lowering the river bottom, which may lead to bank erosion, and a threat to bridges and nearby structures. Other costly effects beyond the immediate mine sites such as loss of large tracks of fertile riverside land and valuable timber resources and wildlife habitats in the riparian areas exist. This results in loss of fisheries productivity, biodiversity, recreational potential, land and aesthetic values. Groundwater table is lowered leaving the drinking water wells on the embankments of these rivers dry. The water quality of the rivers are lowered due to increased short-term turbidity at the mining site caused by suspended sediments from stockpiling, organic particulate matter, and oil spills or leakage from excavation machinery and transportation vehicles. These concerns have also been reported in China [3, 4]; Ghana [5]; Nigeria [6]; Malaysia [7] and India [8,9]. To mitigate this indiscriminate sand mining, initial environmental impact assessment (EIA) for resource extraction should be carried out followed by subsequent ones, as the growing demand renders the existing extraction capacity insufficient [10]. In such cases environmental impact assessment is not an effective tool to protect the environment because the subsequent EIA's gradually change the environment to a scale beyond that envisaged in any individual EIA [11]. This leads to the situation where multiple officially approved projects may have combined impacts, which are undesirable and beyond control of the applied planning and impact assessments instruments [10]. Consequently, strategic environmental assessment would require considering the environmental impacts of exploiting available resources in the light of current and future demand. So far, no such strategic environmental assessment of sand mining has been reported [10].

Whereas mining of river sand for concrete manufacture will still continue unabated, alternative sources of sand need to be explored to reduce environmental degradation associated with river sand mining. In addition, river sand like any other natural resource is limited, and its exploitation and dependency must be minimized in order to promote environmental sustainability. Volcanic pyroclastic materials such as volcanic tuff and lapilli have been proposed as possible alternative to river sand. Volcanic pyroclastic materials are products of volcanic 
eruptions classified according to their size; dust (less than $0.6 \mathrm{~mm}$ ), ash (fragments between 0.6 and $2 \mathrm{~mm}$ ), cinders or lapilli (fragments between 2 and $64 \mathrm{~mm}$ ), blocks (angular fragments greater than $64 \mathrm{~mm}$ ) and bombs (rounded fragments greater than $64 \mathrm{~mm}$ ). Volcanic tuff is a consolidated pyroclastic rock composed of compacted and cemented volcanic ash. The rock is often soft and porous. Texture and chemical or mineralogical composition are variable with ash grain size of below $4 \mathrm{~mm}$. Lapilli is a size classification term for tephra, which is a material that falls out of the air during a volcanic eruption or during some meteorite impacts with a diameter ranging from 2 to $64 \mathrm{~mm}$. Yasin et al. observed that replacing fines aggregates by $20 \%$ volcanic tuff increased concrete compressive strength by $10 \%$ for brown and grey tuff, and 15\% for yellow tuff [12]. AlZou'by and Al-Zboon studied the effect of blending standard sand with volcanic tuff for production of cement mortar and reported that up to 50\% Jordanian volcanic tuff (from Jabal Artin) can improve mortar characteristics and reduce the unit weight of mortar to some extent [13]. The main objective of this study is to evaluate the suitability of volcanic pyroclastic materials especially volcanic tuff and lapilli as possible alternative to river sand as fine aggregates. The evaluation will involve determining their respective gradation, aggregate absorption, workability, compressive strengths, and the optimum river sand replacement that gives maximum concrete strength, and prescribe the best pyroclastic material that can produce high strength lightweight concrete for use in construction works to reduce environmental degradation associated with mining river sand as fine aggregates for concrete manufacture.

\subsection{Aggregates}

\section{Materials and Methods}

Coarse aggregates were obtained from a hard stone quarry in Kayole, Nairobi, Kenya. River sand which was used as fine aggregates was obtained from a river in Mwala, Machakos. Ordinary Portland cement (OPC) was bought from a hardware store in Nairobi, Kenya. Lapilli materials were obtained from a quarry at Kibwezi in Makueni County, Kenya, and volcanic tuff materials were obtained from a quarry at Rhonda, Nakuru County. The coarse and fine aggregates were sampled in accordance with ASTM D75 / D75M -14, Standard Practice for Sampling Aggregates [14]. Fine aggregates used were those retained in No. 4 (4.75mm) sieve and predominately retained on the No. $200(75 \mu \mathrm{m})$ sieve. Particle size distribution was done in accordance with BS 812-103.1:1985, Method for determination of particle size distribution - Sieve tests [15]. Specific gravity and Water absorption tests were done in accordance with ASTM C127-07, 2007. Test Method for density, Relative density (specific gravity), and absorption of coarse aggregates [16].

\subsection{Fresh Concrete}

A mix proportion of 1:2:4 was used to manufacture concrete in accordance with BS 1881-109, 1983 (Method for making test beams from fresh concrete) at a water cement (w/c) ratio of 0.445 [17]. Replacement of river sand with volcanic tuff and lapilli was done at $0 \%, 25 \%, 50 \%, 75 \%$, and $100 \%$ by weight of river sand. Slump test was done in accordance with BS 1881-102, 1983: Method for determination of slump [18]. Compaction factor (CF) was done in accordance with BS 1881-103, 1993: Method for determination of compacting factor [19].

\subsection{Casting and curing of concrete test cubes}

Concrete test cubes were casted in $150 \mathrm{~mm} \times 150 \mathrm{~mm} \times 150 \mathrm{~mm}$ cube steel moulds in accordance with BS 1881-108, 1983: Method for making test cubes from fresh concrete [20], and were cured for 7, 14 and 28 days, and in accordance with BS 1881-111, 1983: Method of normal curing of test specimens (20 ${ }^{\circ} \mathrm{C}$ method) [21].

\subsection{Hardened Concrete}

Water absorption test was carried out on hardened concrete after 28 days cure in accordance with BS 1881-122, 2011: Method for determination of water absorption [22]. Compressive strength tests were carried out at 7, 14, and 28 days, and in accordance with BS 1881-116, 1983: Method for determination of compressive strength of concrete cubes [23].

\subsection{Particle size distribution}

\section{Results and discussion}

Fig. 1 shows the recommended gradation envelope for fine aggregates suitable for concrete and gradation for river sand, volcanic tuff, and lapilli. The results indicate that both river sand and volcanic tuff gradations fall within the required gradation envelope. Lapilli gradation fell outside the required gradation envelope. At a constant water-cement (w/c) ratio, such aggregates will make the mix less workable. In addition, fines modulus (FM) for fine aggregates shall not be less than 2.3 or more than 3.1 (ASTM C33, 2000) [24]. Fine aggregates with FM below 2.3 produce concrete with higher cement requirements if w/c is kept constant. Similarly, fine aggregates with FM greater than 3.1 results in harsh concrete mixes prone to bleeding and 
segregation when used in concrete. The FM for river sand was found to be 3.0 (Table 1) which conforms to the above standards. However, the FM for volcanic tuff and lapill were 3.8 and 5.5 respectively, and coarser in accordance with ASTM C33 [24]. It is therefore desirable to blend these materials with river sand to improve their gradation, workability, and capability of producing high strength concrete.

Table 1 Fines Modulus, Specific gravity and absorption for river sand, volcanic tuff and Lapilli

\begin{tabular}{|l|l|l|l|}
\hline Parameter & River sand & Volcanic tuff & Lapilli \\
\hline Fines Modulus & 3.0 & 3.8 & 5.5 \\
\hline Specific gravity & 2.65 & 2.29 & 2.53 \\
\hline Absorption (\%) & 2.5 & 16.0 & 10.2 \\
\hline
\end{tabular}

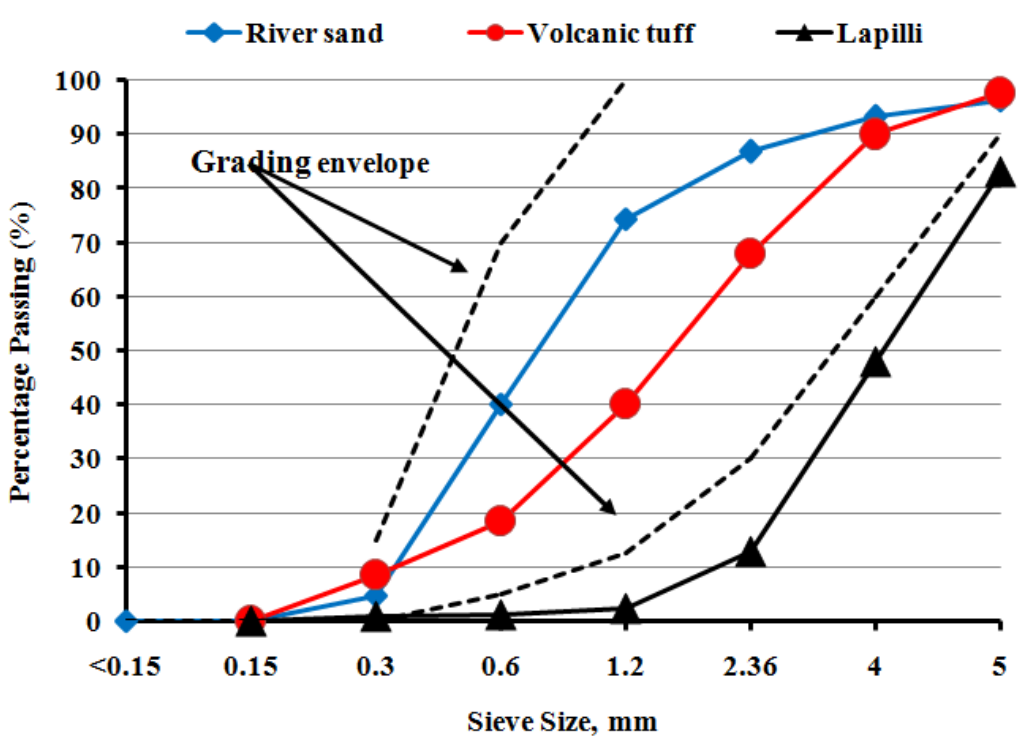

Fig.1. Particle size distribution for river sand, volcanic tuff and Lapilli

\subsection{Workability}

Table 2 shows Slump test and Compaction factor (CF) results for river sand, volcanic tuff, and lapilli at $0 \%, 25 \%, 50 \%, 75 \%$, and $100 \%$ river sand replacement. The results indicate that for volcanic tuff, the slump decreased with increase in river sand replacement. This can be attributed to the increasing water absorption since volcanic tuff is very porous (Table 1). However, slump increased with increase in the amount of lapilli. This can be attributed to the gap grading of the lapilli material, and insufficient water for workability and hydration, hence decreased formation of the cementitious matrix to bind the coarse aggregates. The CF test results indicated a decreased trend as river sand replacement increases for both volcanic tuff and lapilli. This is because as the amount of pyroclastic materials increase at a constant w/c, the surface area for lubrication is increased rendering the mix harsher and difficult to compact. Consequently, the CF test results show a clear state of affairs in the mix as river sand replacement is increased. A close observation of the mix should be made, and water content adjusted where necessary.

Table 2 Slump and Compaction Factor $(\mathrm{CF})$ of fresh blended concrete

\begin{tabular}{|l|l|l|l|l|l|l|}
\hline \multirow{2}{*}{ Fine Aggregates Type } & \multirow{2}{*}{ Parameter } & \multicolumn{6}{|l|}{ River Sand Replacement (\%) } \\
\cline { 3 - 7 } & 0 & 25 & 50 & 75 & 100 \\
\hline Volcanic tuff & Slump (mm) & 60 & 48 & 38 & 31 & 25 \\
\hline & C F & 0.98 & 0.94 & 0.91 & 0.89 & 0.87 \\
\hline Lapilli & Slump (mm) & 60 & 90 & 110 & 130 & 160 \\
\hline & C F & 0.98 & 0.96 & 0.94 & 0.91 & 0.89 \\
\hline
\end{tabular}

\subsection{Water absorption and compressive strength}

Table 3 and Fig. 2 show water absorption and compressive strength test results for $150 \mathrm{~mm}$ x $150 \mathrm{~mm}$ x $150 \mathrm{~mm}$ blended concrete cubes after 28 days curing period for volcanic tuff and lapilli. The results indicate that absorption increases as river sand replacement increases. However, the rate of increase was higher for lapilli blended concrete. This could be due to formation of pervious cementitious matrix caused by insufficient water for workability and hydration due to high surface area for lapilli particles. The compressive strength of volcanic tuff increased as river sand replacement increases from $25.6 \mathrm{kNm}^{-2}$ at the control to an optimum of $27.8 \mathrm{kNm}^{-2}$ at $25 \%$ river sand replacement then falls to $23.2 \mathrm{kNm}^{-2}$ at $100 \%$ river sand replacement. For lapilli material, the 
compressive strength increased steadily from $25.6 \mathrm{kNm}^{-2}$ at the control to an optimum of $27.2 \mathrm{kNm}^{-2}$ at $25 \%$ replacement then fell to $10.9 \mathrm{KN} / \mathrm{m}^{2}$ at $100 \%$ replacement. This could be due to decreased formation of the cementitious matrix attributed to insufficient water for workability and hydration since lapilli materials are finer and consequently have a higher surface area for lubrication. The compressive strength of the control cubes conformed to the theoretical class 25 concrete at day 28 day strength. The results also indicate that replacing river sand with either volcanic tuff or lapilli material up to $50 \%$ still gives concrete with higher compressive strength $\left(27.1 \mathrm{kNm}^{-2}\right.$ and $26.8 \mathrm{kNm}^{-2}$ respectively) than the control strength of $25.6 \mathrm{kNm}^{-2}$. In order to reduce environmental degradation associated with mining of river sand, volcanic tuff or lapilli materials can be used to replace river sand up to $50 \%$ for class 25 concrete.

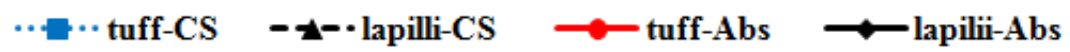

CS-Compressive Strength, Abs-Absorption

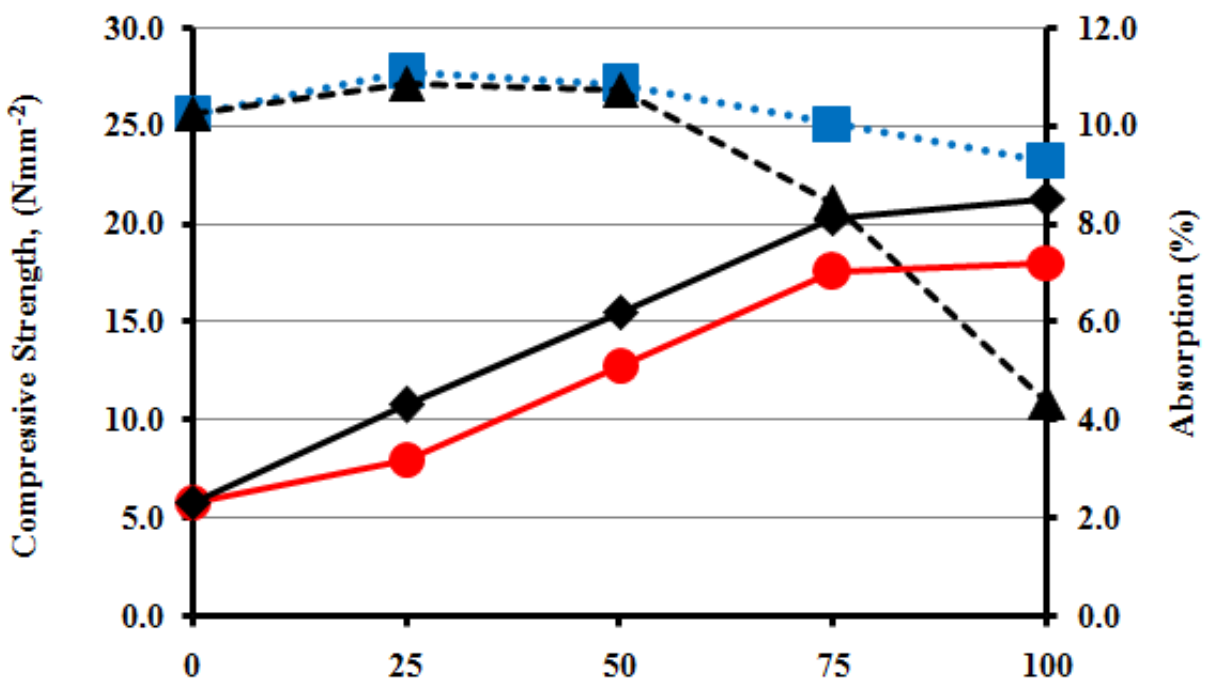

River Sand Replacement (\%)

Fig. 2. Water absorption and compressive strength for $150 \mathrm{mmx} 150 \mathrm{mmx} 150 \mathrm{~mm}$ blended concrete test cubes after 28 days cure

Table 3 Absorption and compressive Strength $\left(\mathrm{Nmm}^{-2}\right)$ for $150 \mathrm{mmx} 150 \mathrm{mmx} 150 \mathrm{~mm}$ blended concrete test cubes after 28 days curing period.

\begin{tabular}{|c|c|c|c|c|c|c|}
\hline \multirow{2}{*}{ Fine Aggregates Type } & \multirow[b]{2}{*}{ Parameter } & \multicolumn{5}{|c|}{ River sand replacement (\%) } \\
\hline & & 0 & 25 & 50 & 75 & 100 \\
\hline \multirow[t]{2}{*}{ Volcanic tuff } & Absorption (\%) & 2.3 & 3.2 & 5.1 & 7.0 & 7.2 \\
\hline & Compressive Strength $\left(\mathrm{Nmm}^{-2}\right)$ & 25.6 & 27.8 & 27.1 & 25.1 & 23.2 \\
\hline \multirow[t]{2}{*}{ Lapilli } & Absorption (\%) & 2.3 & 4.3 & 6.2 & 8.1 & 8.5 \\
\hline & Compressive Strength $\left(\mathrm{Nmm}^{-2}\right)$ & 25.6 & 27.2 & 26.8 & 21.0 & 10.9 \\
\hline
\end{tabular}

\section{Conclusions}

1. The results of this study have shown that the workability of fresh concrete blended with both volcanic tuff and lapilli decreases as the amount of river sand replacement is increased making the mix difficult to compact. This is because at a constant w/c, water for lubrication is insufficient to suffice the increased surface area of the pyroclastic particles.

2. The water absorption of the $150 \mathrm{~mm} \times 150 \mathrm{~mm} \times 150 \mathrm{~mm}$ concrete cubes at 28 day curing period increased as the amount of sand replacement increases. This followed the trend of individual particles.

3. The compressive strength of the blended concrete increased from the control $25.6 \mathrm{Nmm}^{-2}$ ( $0 \%$ replacement) to an optimum of $27.8 \mathrm{Nmm}^{-2}$ and $27.2 \mathrm{Nmm}^{-2}$ at $25 \%$ river sand replacement for volcanic tuff and lapilli respectively indicating that both volcanic tuff and lapilli materials have pozzolanic properties resulting into blended concrete much stronger in strength compared to the conventional concrete. This increase is 9 and $6 \%$ for volcanic tuff and lapilii respectively at $25 \%$ river sand replacement. 
4. The pyroclastic material studied in this research (volcanic tuff and lapilli) have low specific gravity; volcanic tuff (2.29) and lapilli (2.53) capable of producing lightweight concrete of class 25.

5. The results have shown that volcanic tuff or lapilli materials can be used to replace river sand up to $50 \%$ for class 25 concrete. This would reduce environmental degradation associated with mining of river sand.

\section{Acknowledgements}

The authors are grateful to the Technical University of Kenya Department of Civil and Construction Engineering for allowing us to use their concrete laboratory for this research.

\section{References}

[1]. R.D. Barksdale. The aggregate handbook. National Stone Association, Washington D.C. 1991

[2]. G.M. Kondolf. Hungry water: Effects of dams and gravel mining on river channels. Environ. Manage. 21(4), 1997, 533-551.

[3]. G. Wu, J. de Leeuw, A.K. Skidmore. H.H.T. Prins. Y. Liu. Concurrent monitoring of vessels and water turbidity enhances the strength of evidence in remotely sensed dredging impact assessment. Water Res. 41, 2007, 3271-3280.

[4]. X.X. Lu, S.R Zhang. S.P. Xie, P.K. Ma. Rapid channel incision of the lower Pearl River (China) since the 1990s. Hydrol. Earth Syst. Sc. Discuss. 4, 2007, 2205-2227.

[5]. J.V. Mensah . Causes and effects of coastal sand mining in Ghana. Singap. J. Trop. Geogr. 18, 2002, 69-88.

[6]. A.B. Nabegu. Effect of sand mining on groundwater in Kano River catchment. J. Environ. Earth Sc. 3(2), $2013,81-87$.

[7]. M.A. Ashraf, M.J. Maah, I. Yusoff, A. Wajid, K. Mahmood. Sand mining effects, causes and concerns: A case study from Bestari Jaya, Selangor Peninsular, Malaysia. Sci. Res. Essays. 6(6), 2011, 1216-1231.

[8]. D. Padmalal, K. May, S. Sreebha, R.Sreeja. Environmental effects of river sand mining: a case from the river catchments of Vembanad Lake, Southwest coast of India. Environ. Geol. 54, 2008, 879-889.

[9]. Sreebha S. Padmalal D. Environmental impact assessment of sand mining from the small catchment rivers in the Southwestern Coast of India: A case study. Environ. Manage. 47, 2011, 130-140.

[10]. J. de Leeuw, D. Shankman, G. Wu, W.F. de Boer, J. Bunham, Q. He, H.Yesou, J. Xiao. Strategic assessment of the magnitude and impacts of sand mining in Poyang Lake, China. Reg. Environ. Change. 10, 2010, 95-102.

[11]. Y. Wang, R. Morgan M. Cashmore. Environmental impact assessment of projects in the People's Republic of China: new law, old problems. Environ. Impact Assess. Rev. 23, 2003, 543-579.

[12]. A.A. Yasin, M.T. Awwad, H.R. Hajjeh, E.I. Sahawneh. Effect of volcanic tuff on the concrete compressive strength. Contemp. Eng. Sci. 5(6), 2012, 295-306.

[13]. J, Al-Zou'by, K.K. Al-Zboon. Effect of volcanic tuff on the characteristics of cement mortar. Ceramica. 60, 2014, 279-284

[14]. ASTM D75 / D75M -14, 2014. Standard Practice for Sampling Aggregates. ASTM International, West Conshohocken, PA, USA

[15]. BS 812-103.1 (1985) Method for determination of particle size distribution — Sieve tests. British Standard Institute, London, UK

[16]. ASTM C127-07(2007) Test Method for density, Relative density (specific gravity), and absorption of coarse aggregates. ASTM International, West Conshohocken, PA, USA.

[17]. BS 1881-109 (1983) Method for making test beams from fresh concrete. British Standard Institute, London, UK

[18]. BS 1881: Part 102 (1983) Methods for determination of slump. British Standard Institute, London, UK.

[19]. BS 1881: Part 103 (1993) Method for determination of compacting factor. British Standard Institute, London, UK.

[20]. BS 1881-108 (1983) Method for making test cubes from fresh concrete. British Standard Institute, London, UK.

[21]. BS 1881: Part 111 (1983) Method of normal curing of test specimens ( $20^{\circ} \mathrm{C}$ method). British Standard Institute, London, UK.

[22]. BS 1881: Part 122 (2011) Method for determination of water absorption. British Standard Institute, London, UK.

[23]. BS 1881-116 (1983) Method for determination of compressive strength of concrete cubes. British Standard Institute, London, UK.

[24]. ASTM C 33-00 (2000) Standard Specification for Concrete Aggregates. ASTM International, West Conshohocken, PA, USA. 